\title{
THE ATTITUDE TOWARDS PEOPLE OF OTHER NATIONS THROUGH THE PRISM OF THE ATTITUDE TO YOURSELF
}

\author{
Olha Konyukh \\ Faculty of Philosophy, Ivan Franko National University of Lviv \\ Universytetska St. 1, Lviv, 79000, Ukraine \\ E-mail address: oliakonyukh@gmail.com

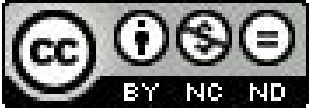

\begin{abstract}
The article presents the results of theoretical analysis and empirical investigation of the relationship between self-attitude and attitude towards other people, including representatives of other nationalities. Self-attitude is viwed as a stable, emotionally charged of your own self. The interdependance of self-attitude indicators with the features of ethnic tolerance and the character of other individuals' attitude in complicated situations has been researched. Individuals with different self-image are shown to perceive their opponents just as they perceive their own personality. Perception and emotional attitude both to their own ethnic group and other ethnicities is closely related to the attitude of the individual to himself, and common factors in predisposition to criticism and condescension towards themselves and others.
\end{abstract}

Keywords: self-attitude, identity, self-consciousness, self-image, ethnic identity, tolerance, communicative tolerance, ethnic nihelism, ethnic egotism.

\section{INTRODUCTION}

Not only does the human explore the world but also expresses attitude towards it and themselves in the world. Self-attitude is an integral part of human manifestation as a conscious subject, their attitude towards the surrounding world and other people.

A significant number of researches has been conducted in psychology, wherein the close connection between the personality's attitude toward themselves as subject of social relations and their behaviour (Antonina Alekseeva, Leonid Kyrylov, Lyudmyla Kornieeva, Maya Lisina, Heinz Heckhausen and others). Carl Rogers (1995) argues that high self-respect of the individual stands as a condition of its activity, productivity, realization of creative potential, impacts the freedom of feelings expression and self-revelation in communication . Positive, sustainable selfattitude lies at he heart of human self-confidence in their abilities, it is associated with psychological resources in a situation of uncertainty (Lyubymova, 2011, pp. 48-52). 
According to Serhey Bratchenko (2003, pp. 104-117), personality self-attitude also influences the attitude to others, tolerant, respectful and receptive self-attitude is a personalized foundation of interpersonal tolerance. In this sense, the level of tolerance is closely related to the level of self-acceptance and self-esteem which, in a sense, can be regarded as a manifestation of tolerance to oneself .

Personality self-attitude in modern science is usually viewed as an emotional component in the structure of consciousness (Stolin, 1983). The attitude of the individual to themselves as the emotional component of self-identity often results from assessment of cognitive components. (Chesnokova, 1977), where the personality's own attitude to things that they learn, understand, reveal for themselves, is reflected. At the same time, worry is understood as an internal dynamic basis, the method for self-attitude existence, through which a person realizes a valuable sense of self-attitude (Chesnokova, 1977, p. 117).

Another important aspect in assessing a personality is an image of the Perfect $E g o$ as a certain standard. In this case, C. Rogers pointed out that the longer a person is on the axis of their ideals, the more troubled they are. They scientist stressed that each other's approaching to Real Ego and Perfect Ego images is an important aspect of self-development, their greater adaptability and self-confidence. And it is the unconditional acceptance by others - in the definition of $\mathrm{C}$. Rogers (1995, p. 37), definitely is a positive attitude. It allows a person to open up, be themselves, and accept themselves, knowing that others appreciate, love, and respect them, no matter what kind of person they are.

When analyzing C. Rogers' theory, David Guy Myers (2013), argues that since people are accepted and appreciated, they develop a more attentive attitude to themselves. Moreover, one can fix the following pattern: when a person perceives their inner world positively, the attitude towards others will be positive as well. As opposed to the situation when a person is not satisfied with their inner world, regardless, the awareness, the surrounding people's world seems negative or even hostile, that is, one a person needs to be protected from.

By the mediation of psychological defense mechanisms, including projection, the unconscious mechanism through which impulses and feelings that are unacceptable to the individual, are attributed to external objects and penetrate the consciousness as a changed perception of the external world (Freud, 1993), a human transforms their attitude to the inner Ego on the external, objective relationships with others in social reality. Thus, it is internal, unresolved conflicts that become the basis for interpersonal perception, attitude towards people similar and different from themselves, perception of otherness and assumption of social environment invariance.

According to Aleksandr Spirkin (1972, pp. 149-155), self-attitude enables the individual to understand themselves through understanding their own attitude to the world, to other people, and the nature of their own activity and its results .Human self-attitude affects the attitude to the others. This is particularly evident in problematic and unusual situations, such as communication with other ethnic groups. Tolerance, in particular ethnic tolerance, is not possible without mental stability and personal maturity. In the study of ethnic tolerance, Elena Shlyahina (2001), highlights the following determining personality qualities: self-esteem, psychologi- 
cal age, level of self-actualization, formation of the real and ideal Ego, the hierarchy of needs, type of interpersonal relationship, type of behavior in conflict situations .

Ethnic tolerance is considered to be a sign of a mature personality with stable Ego-concept and distinct identity. Scientists like Yuryk Harutyunyan, Leokadyya Drobyzheva, Nadezhda Liebedeva and Aleksandr Tatarko emphasize that positive ethnic identity is a prerequisite for tolerance. So far, the availability of positive image of other cultures representatives is characteristic for the ethnically tolerant personality provided that the positive image of their own culture and themselves are present (Tatarko, Liebedeva, 2010, pp.54-55)

\section{THE INVESTIGATION PROCEDURE}

The object of our research was the detailed study of the interdependence of internal self-image, self identity and attitude to representatives of other nationalities, like susceptibility to ethnic tolerance.

The hypothesis of the research is that people who are likely to be satisfied with their personality, possess a positive self-image and accept both their own positive traits and weaknesses, will treat people who do not belong to their reference group in a similar way, and will be prone to ethnic tolerance.

The study was conducted among university students in four cities of Ukraine; 401 people took part in total. Sample characteristics: the age of people under research - 19-25 years division by gender - 291 women and 110 men. $89 \%$ of study participants live in cities, $37 \%$ regularly and $56 \%$ occasionally come into contact with representatives of other nationalities. As for nationalities surveyed, $98 \%$ of the people under survey stated they were Ukrainians.

Apparently, the sample is sufficiently uniform and represents young Ukrainians who obtain the higher education and are open to dialogue with the representatives of other ethnic groups.

The research was conducted using a written survey, standardized methods and unique questionnaires.

The study used methods for the diagnosis of self-attitude, like the methodologies of Vladimir Stolin, Serhey Pantilieev personality self-attitude (Pantilieev, 1993) and the diagnostic test of attitudes by Halyna Soldatova, which was also used for the study of auto- and hetero-stereotypes. The sample of ethnic tolerance was performed using a quick questionnaire called Index of Tolerance by Halyna Soldatova (2008), Oksana Kravtsova, and the methodology by Halyna Soldatova and Svetlana Ryzhova called Types of ethnic identity To investigate the activity side of tolerance, the methodology of the research of general communicative tolerance by Viktor Boyko, was used (Soldatova, 2008).

Personality self-attitude Research Methodology by V. V. Stolin and S. R. Pantilieev (1993) is designed to detect personality self-attitude structures, as well as the severity of individual components of self-attitude sincerity, self-confidence, self-management, reflected self-attitude to self-awareness, self-acceptance of inner proneness to conflict and self-accusation. 
The basis of self-attitude understanding is the concept of self-awareness by $\mathrm{S}$. R Pantilieev (1993), who distinguished three dimensions self-attitude: sympathy, respect, intimacy.

Three independent factors that can be easily interpreted may be distinguished as based in the said methodology. The first factor was created by the flurry of inner honesty, self-confidence, self-management and reflected self-attitude. They can be combined into one factor since all of them express the evaluation of their own Ego respondents regarding social and regulatory criteria of morality, success, freedom, commitment, social approval, etc., which enables us to interpret this factor as a self-esteem. The second factor includes three scales: self-value, selfacceptance and self-affection. These scales are not associated either with socially normative criteria, or with the personality traits and character of the object. They reflect, in the most pure form, the emotional attitude to the subject, to their own Ego. Therefore, they can be interpreted as scales of auto-affection.

The third factor includes scales of the internal proneness to conflict and selfaccusation associated with negative self-attitude, therefore it is called self-abasement (Pantilieev, 1991).

The diagnostic test of attitudes is an original modification of semantic differential method that allows study of inter-ethnic and interpersonal relationships, as well as interpersonal attitude reflects the emotional component of social stereotypes and ethnic tolerance. The methodology on the idea that the same qualities are attributed to both themselves and others, can be interpreted in different ways: the positive qualities of their group (e.g, We are thrifty and economic) may be perceived as a negative trait in another group (they are greedy, stingy). The pairs of qualities have been compiled according to the said principle.

Their poles differ in affective parameters, while their content may be close enough. The following pairs of qualities were suggested: diplomatic - hypocritical; active - aggressive; economical - greedy; temperamental - excited; obsessive - sociable; characterless - agreeing, stubborn - intrusive, pedantic - neat, proud arrogant, witty - malicious, inventive - cunning, cautious - craven.

The methodology of ethic identity types diagnostics by H.U. Soldatova, S.V Ryzhova has also been used. The authors of present technique distinguish identity types in accordance with the level of ethnic tolerance from ethnic nihilism to ethnic fanaticism. They also introduce the notion of a norm or positive ethnic identity, which presupposes a clear own identity and tolerant attitude towards other ethnic groups (Soldatova, 2008).

Processing of research results was carried out using statistical methods of data processing (computer package STATISTICA, version 8.0).

\section{THE RESULTS OF THE RESEARCH}

the assumptions regarding the differences in attitude to others in individuals with different self-attitude was confirmed after the results analysis of the meaningful methodology Diagnostic test of attitudes. We divided the people sur- 
veyed into two groups with predominance of positive and negative features in the self-description, and compared their vision of their own and other nationalities. Thus, personalities who describe themselves using mostly positive attributes, are more inclined to celebrate the positive qualities of ethnic group as a whole, whereas persons who were credited with unattractive traits, clearly tend to see the negative in other people. Although the substantial set of features in the description of ethnic groups coincides in both groups. Let's illustrate this in a diagram.

Fig. 1. Differences in description of their own nationality among those with the

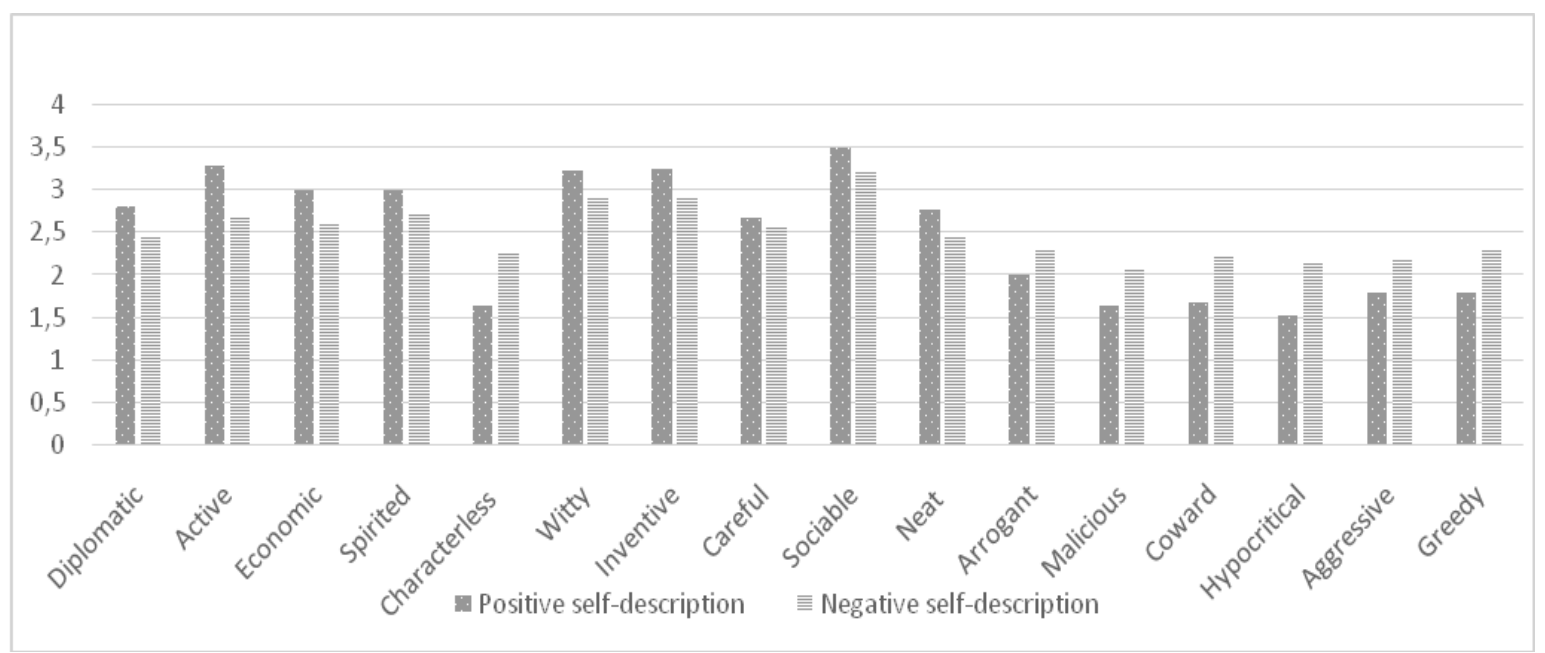

most positive and most negative self-description.

Source: Own research.

Thus, we can observe that persons prone to describe themselves using positively charged personal qualities, motly distinguish such positive qualities as diplomacy, activity, and sociability, when describing their own nation. Individuals who are more concentrated on their own shortcomings, are more likely to notice negative traits, like cowardice, hypocricy, aggression, greed.

H. U. Soldatova (2008) in her writings describes normal or positive ethnic identity as a combination of positive attitude towards their own people with a positive attitude to other people, which is essential for harmonious inter-ethnic relations, when neither party is deprived of rights . In our study, positive ethnic identity correlates with indicators like self-attitude, self-confidence, reflected self-attitude and self-value.

Tab. 1. The correlation of positive ethnic identity with the components of self-attitude

\begin{tabular}{|l|c|l|l|}
\hline & Self-confidence & Reflected self-attitude & Inherent value \\
\hline Positive ethnic identity & $\mathrm{r}=0,13, \mathrm{p}<0,05$ & $\mathrm{r}=0,11, \mathrm{p}<0,05$ & $\mathrm{r}=0,11, \mathrm{p}<0,05$ \\
\hline
\end{tabular}

Source: Own research. 
Thus, a positive attitude to other ethnic personality, which retains their own ethnic identity, is combined with self-confidence, a sense of one's own Ego, courage in communicating and sense of own life competence, i. e the ability to overcome obstacles and achieve goals. Additionally, a person who favors different ethnic groups, expects positive attitude towards themselves from others, they are open to communication. They appreciate their own individuality and are ready for self-expression. Therefore, having summarized the correlation, we can see that the person who does not feel hostility on the part of others and is confident in their expertise and value, does not need to defend themselves from the influence of other persons who may carry different values, since their identity is formed and does not need excessive opposition, which is often a mechanism of personality ethnic identification (Waltzer, 2000, p. 28)

Tab. 2. The correlation of a positive ethnic identity with the scales of diagnostic attitudes tests.

\begin{tabular}{|l|l|l|l|l|l|}
\hline & $\begin{array}{l}\text { Coefficient of } \\
\text { self-attitude }\end{array}$ & $\begin{array}{l}\text { Coefficient of } \\
\text { the attitude } \\
\text { towards } \\
\text { Ukrainians }\end{array}$ & $\begin{array}{l}\text { Coefficient of } \\
\text { the attitude } \\
\text { towards } \\
\text { Belorussians }\end{array}$ & $\begin{array}{l}\text { Coefficient of } \\
\text { the attitude } \\
\text { towards } \\
\text { French }\end{array}$ & $\begin{array}{l}\text { Coefficient of } \\
\text { the attitude } \\
\text { towards } \\
\text { Englishmen }\end{array}$ \\
\hline $\begin{array}{l}\text { Positive ethnic } \\
\text { identity }\end{array}$ & $\mathrm{r}=0,14, \mathrm{p}<0,05$ & $\mathrm{r}=0,19, \mathrm{p}<0,05$ & $\mathrm{r}=0,14, \mathrm{p}<0,05$ & $\mathrm{r}=0,14, \mathrm{p}<0,05$ & $\mathrm{r}=0,15, \mathrm{p}<0,05$ \\
\hline
\end{tabular}

Source: Own research.

Relationship of positive ethnic identity with scales of semantic differential indicate prevalance of positive stereotypes about different nationalities.

Considering the deviation from the normal identity towards either ethnic indifference or aggravation or ethnocentric views, we see that these identities are often combined with internal conflictual identity when the negative background of self-attitude prevails, with a tendency to constant self-analysis, distance of Real Ego and Perfect Ego image.

Tab. 3. The correlation of ethnic nihilism with the scales of tolerance and self-attitude.

\begin{tabular}{|l|l|l|l|l|l|}
\hline & $\begin{array}{l}\text { Tolerance as a } \\
\text { feature }\end{array}$ & $\begin{array}{l}\text { Rejection of } \\
\text { others }\end{array}$ & $\begin{array}{l}\text { Categoricity in } \\
\text { the estimation } \\
\text { of others }\end{array}$ & $\begin{array}{l}\text { Internal } \\
\text { proneness to } \\
\text { conflict }\end{array}$ & Self-accusation \\
\hline $\begin{array}{l}\text { Ethnic } \\
\text { nihilism }\end{array}$ & $\begin{array}{c}\mathrm{r}=-0,13, \\
\mathrm{p}<0,05\end{array}$ & $\mathrm{r}=0,3, \mathrm{p}<0,05$ & $\mathrm{r}=0,2, \mathrm{p}<0,05$ & $\begin{array}{l}\mathrm{r}=0,19, \\
\mathrm{p}<0,05\end{array}$ & $\mathrm{r}=0,12, \mathrm{p}<0,05$ \\
\hline
\end{tabular}

Source: Own research.

It is interesting that ethnic nihilism characterized by vagueness and uncertainty of ethnic identity is interconnected with low personal tolerance and correlates with high levels of communicative intolerance, which is manifested in intemperance, categoricity in the estimations, indifference to the feelings of others and attempts to adjust the 
surrounding people to themselves. This form of identity is combined with negative stereotypes not only for their own nationality, but also regarding the majority of etnosts, proposed in the questionnaire. What concerns the self-attitude with this type of identity, it is characterized by proneness to conflicts and a tendency to self-accusation. Thus, the research results demonstrate that negative self-attitude as well as intolerance to their own ethnic group and vague identity causes negative attitude towards the personality to others. In such case, one can argue about the transformation of interpersonal conflict into an external conflict, as was pointed out above.

Considering interrelations of identity by the type of ethnic fanaticism, characterized by the opposite phenomena, namely the rise of their own ethnic group and disregard for others, one can observe the correlation with the same tolerance and self-attitude indicators, as in the previous case.

Tab. 4. The correlation of ethnic fanaticism with the scales of tolerance and self-attitude.

\begin{tabular}{|l|l|l|l|l|l|}
\hline & $\begin{array}{l}\text { Tolerance as a } \\
\text { feature }\end{array}$ & $\begin{array}{l}\text { Rejection of } \\
\text { others }\end{array}$ & $\begin{array}{l}\text { Categoricity in } \\
\text { the estimation } \\
\text { of others }\end{array}$ & $\begin{array}{l}\text { Internal } \\
\text { proneness to } \\
\text { conflict }\end{array}$ & Self-accusation \\
\hline $\begin{array}{l}\text { Ethnic } \\
\text { fanaticism }\end{array}$ & $\begin{array}{l}\mathrm{r}=-0,28, \\
\mathrm{p}<0,05\end{array}$ & $\mathrm{r}=0,17, \mathrm{p}<0,05$ & $\mathrm{r}=0,3, \mathrm{p}<0,05$ & $\begin{array}{l}\mathrm{r}=0,19, \\
\mathrm{p}<0,05\end{array}$ & $\mathrm{r}=0,13, \mathrm{p}<0,05$ \\
\hline
\end{tabular}

Source: Own research.

Thus, it is likely that the worry about their own weakness and internal conflict can be compensated by diminution of the value of others; hostility toward other nationalities may be an attempt to form and protect their own identity, when a person is not sure about the positiveness and value of it.

By means of cluster analysis, namely cluster tree, we divided individuals with various self-attitude, and obtained four different groups of individuals under research.

The first cluster included individuals under research who were characterized by high levels of self-management, self-acceptance, self-affection along with high levels of inner conflict and tendency to self-incrimination. Persons with this type of self-attitude can be described as self-critical, having a quite stable inner core, being responsible for themselves and their actions, having emotional attachment to their inner Ego. Such individuals are rather scrupulous to their weaknesses, blame themselves for all their failures and often experience dissatisfaction.

The second cluster included self-satisfied individuals who were not self-critical and were characterized by high levels of positive self-attitude at all scales and low self-criticism; they were not prone to self-incrimination. Such individuals are not inclined to engaging in self-reflection of their inner world, they are responsible for themselves, confident in their abilities, expect a positive attitude from others, find their identity to be valuable and perceive it with all its positive and negative qualities. Such individuals are not inclined to deep analysis of their failures or problems. 
Individuals who were included into the third cluster can be described as deeply dissatisfied with themselves and are prone to maladjustment and inner dissatisfaction. This cluster consisted of the individuals under research who received low scores according to the scales of positive self-attitude and were prone to severe self-criticism and self-incrimination. Therefore, they are not confident, can be easily indluenced from the outside and shift responsibility to external factors, expect mostly negative attitude to themselves from the others, do not show interest in their own inner world, to which they have negative attitude and tend to see themselves in the good light. Such individuals often experience the feeling of guilt they may not be aware of, emotions regarding themselves are mostly negative.

The fourth cluster is characterized by the inert, negatively charged attitude of individuals under research to themselves. Such persons find it difficult to manage themselves, they are not inclined to resist external circumstances and often remain dissatisfied with themselves. However, they are not overly self-critical, find their personality to be valuable enough and have clearly expressed negative attitudes about their own Ego.

The comparison of mean values according to tolerance indicators in these four clusters, using Henry Scheffe criterion, enabled us to trace the dependence of ethnic tolerance from personality self-attitude.

Let us consider the differences between individuals included into different clusters according to the ethnic identity indicators. Thus, in comparison to others, individuals included into the second cluster are characterized by normal ethnic identity. Therefore, personlaities who are pleased with themselves and are not self-critical, are able to positively treat representatives of other nationalities, while maintaining a positive attitude to their own ethnic group. It is shown, that while being satisfied by both their own personality and ethnic affiliation, such individuals are not inclined to hostile attitude towards other ethnicities.

Instead, individuals who were part of the third cluster and are characterized by deep dissatisfaction with their own personality, differ from other clusters and have the highest indicators according to the scales of ethnic egotism and ethnic nihilism. They have negative attitude towards their own ethnic group, they do not identify themselves as a part of it, while experiencing tension and irritation during contact with other ethnic groups. This attitude toward others as representatives of both their own and different nationality coincides with the attitude of such people to themselves - the proness to see themselves in a negative light, constant dissatisfaction with their own personality and results of their actions.

When comparing clusters according to communicative tolerance indicators, we see that individuals of the fourth cluster are the most susceptible to rejection by others. The negative image of their own Ego previlas, such persons tend not to accept the identity of others, are irritated by the close contact with vivid and eccentric personalities. Moreover, individuals with such self-attitude are uncontrollable in communication and seldom hide their dissatisfaction and irritation.

The individuals of the third cluster are themost critical to shortcomings of other persons, which again reflects their own self-criticism and constant dissatisfaction with themselves. They are the least inclined to forgive the shortcomings of others and inconveniences inadvertently caused by them. 
As opposed to them, individuals characterized by uncritical and positive attitude to themselves and belonging to the third cluster, are most likely to act and calmly accept behavioral patternas and thoughts of their interlocutors that differ from their own.

\section{CONLUSIONS}

The study shows that ethnic tolerance and self-attitude are interdependent phenomena and often affect the formation of each other. The research confirms our hypothesis that people who are likely to be satisfied with their personality, possess a positive self-image and treat people belonging to different ethnic group in a similar way. We noticed a strong relation between self-criticism and rejection of the shortcomings of others. Moreover, the following pattern is noticed: people who are not self-confident and can be easily indluenced from the outside, and shift responsibility to others, mostly expect negative attitude towards themselves from others and are very critical towards themselves and surrounding people; they have negative attitude to other ethnicities while lacking positive identification with their own enthic group. Thus, we can conclude that ethnic tolerance or intolerance depends on individual predisposition to positively or negatively treat others, regardless of their ethnic affiliation, the ability to accept people as they are with their individuality and differences. Such perception is possible only if congruent and positive attitude towards themselves is present, when a person considers themselves worthy, valuable and able to manage their own lives and are not subject to constant self-analysis and destructive self-criticism. We see prospects for further research in a more detailed study of the influence of self-attitude on formation of inter-ethnic relations and worldview, as well as valuable sphere of the individual in matters related to the search of a dialogue and principles of non-violent ways to resolve ethnic conflicts. Since the topic of tolerance and inter-ethnic relations is becoming more sensitive, especially in the Ukrainian society, it important for us to practically implement the principles of public opinion formation, as well as establishment of specific tools to address inter-ethnic tension that permeates all aspects of life.

\section{REFERENCES}

Bratchenko, S. (2003). Психологические основания исследования толерантности в образовании [Psychological grounds for the research of tolerance in education]. Педагогика развития: ключевые компетентности и их становление. 104-117.

Chesnokova, I. (1977). Проблема самосознания в психологии [The issue of self-consciousness in psychology]. Moscow: Сенс.

Freud, A. (1993). Психология Я и защитные механизмы [The Ego and the Mechanisms of Defense]. Moscow: Pedagogy.

Lyubymova, O. (2011). Самоотношение в контекстах эмпирики современных социальнопсихологических исследований девиантного поведения [Self-attitude in the contexts empirics of modern social and psychological researches of deviant behaviour]. Вестник Алтайского государственного университета 2, 48-52. 
Myers, D. (2013). Социальная психология [Social psychology]. St. Petersburg: Питер.

Pantilieev, S. (1991). Самоотношение как эмоционально-оценочная система [Self-attitude as an emotional and Evaluation System]. Moscow: Moscow State University.

Pantilieev, S. (1993). Методика исследования самоотнотения [The methodology self-study]. Moscow: Сенс.

Rogers, C. (1995). On Becoming a Person: A Therapists View of Psychotherapy. Boston: Houghton Mifflin Harcourt.

Shlyahina, E. (2001). Этническая толерантность личности: опыт эмпирического исследования [Ethnic tolerance of the personality: the experience of empiric research]. Ера толерантности, 3-4, 124-131.

Soldatova, Н. (2008). Психодиагностика толерантности личности [Personality tolerance psychodiagnostics]. Moscow: Сенс.

Spirkin, А. (1972). Сознание и самосознание [Consciousness and self-awareness]. Moscow: Политиздат.

Stolin, V. (1983). Самосознание личности [Self-consciousness of the person]. Moscow: Moscow State University.

Tatarko, A., Liebedeva, N. (2010). Психология межэтнических отночений: этническая идентичность и стратегии межкультурного взаимодействия [Psychology of inter-ethnic relations: ethnic identity and strategies of intercultural interaction]. Saarbrucken: LAPLAMBERT Academic Publishing $\mathrm{GmbH}, \& \mathrm{Co}$.

Waltzer, M. (2000). O толерантности [About tolerance]. Moscow: The Home of an intellectual Book. 